\title{
Investigating the Effect of Geometrical and Dynamic Parameters on the Performance of Darrieus Turbines: A Numerical Optimization Approach via QBlade Algorithm
}

\author{
Abdullah MURATOĞLU*, Muhammed Sungur DEMİR \\ Batman Üniversitesi, Inşaat Mühendisliği, Batman \\ (ORCID: 0000-0001-8981-5983) (ORCID: 0000-0003-3631-6325)
}

\begin{abstract}
Increasing energy demand, rising per capita energy use, growing climate problems and other detrimental consequences of energy and environmental issues have prompted scientists and engineers to conduct more studies on the technical feasibility and efficiency of renewable energy conversion systems. Free flow (wind and hydrokinetic) turbines are one of the mostly investigated renewable energy technologies and Darrieus turbines have an exceptional place especially for smaller scale and domestic applications. Many experimental and computational studies have been provided on the performance of Darrieus turbines. However, the number of numerical studies which are more time and cost effective than computational and experimental works are quite limited in the literature. The main objective of this study is to analyze Darrieus turbines at different geometrical and dynamic configurations using numerical QBlade software. In this study, the effect of airfoil selection, number of blades, chord length, solidity and helicity are analyzed in terms of delivering higher performance at straight bladed Darrieus turbines. It has been found that NACA 0020 profile performs better relative to other symmetrical blade sections in vertical axis turbines. Better performance and wider TSR range is obtained for three bladed turbines. Also, increasing chord lengths delivered maximum power at lower tip speed ratio (TSR) ranges. This study is expected contribute site-dependent Darrieus turbine design works at different dimension and dynamic scales for both wind and hydrokinetic applications.
\end{abstract}

Keywords: QBlade, numerical, H-shaped, Darrieus, TSR, solidity, helicity.

\section{Geometrik ve Dinamik Parametrelerin Darrieus Türbin Performansı Üzerindeki Etkisinin Araştırılması: QBlade Algoritması ile Sayısal Optimizasyon}

\begin{abstract}
$\ddot{O} \mathbf{z}$
Artan enerji talebi, kişi başına düşen enerji kullanımı, çevresel problemler ve bunlara bağlı diğer olumsuz sonuçlar bilim insanlarını ve mühendisleri yenilenebilir enerji sistemlerinin verimliliği konusunda daha fazla çalışma yapmaya sevk etmiştir. Serbest akışlı (rüzgâr ve hidrokinetik) türbinler, üzerinde en çok araştırma yapılan yenilenebilir enerji teknolojileri olup Darrieus türbinleri özellikle küçük ölçekli ve lokal uygulamalarda önemli bir yere sahiptir. Darrieus türbinlerinin performansı hakkında birçok deneysel ve hesaplamalı çalışma yapılmış olmasına rağmen, zaman ve maliyet açısından nispeten çok daha elverişli olan numerik çalışmaların sayısı oldukça sınırlıdır. Bu çalışmanın temel amacı, farklı geometrik ve dinamik konfigürasyonlara sahip Darrieus türbinlerinin QBlade yazılımı kullanılarak analiz edilmesidir. Mevcut çalışmada, düz kanatlı Darrieus türbinlerinden daha yüksek performans elde edilmesi amacı ile kanat profili, kanat sayısı, kord uzunluğu, solidite ve sarmallığın performansa etkisi analiz edilmiştir. Bu çalışmada NACA 0020 profilinin, dikey eksen türbinlerde diğer simetrik kanat kesitlerine nazaran daha iyi performans gösterdiği bulunmuştur. Üç kanatlı türbinlerin daha geniş TSR aralığında çalıştığı ve yüksek performans sergilediği tespit edilmiştir. Ayrıca, kord uzunluğu arttıkça maksimum güç katsayısına daha düşük uç hız oranında (TSR) ulaşıldığı tespit edilmiştir. Bu çalışmanın hem rüzgâr hem de hidrokinetik uygulamalar için farklı boyut ve dinamik ölçeklere sahip Darrieus türbini tasarımı çalışmalarına katkıda bulunması beklenmektedir.
\end{abstract}

Anahtar kelimeler: QBlade, sayısal, düz kanatlı, Darrieus, TSR, solidite, sarmallık.

*Corresponding author: abdullah.muratoglu@batman.edu.tr

Received: 19.01.2020, Accepted: 10.02.2020 


\section{Introduction}

Life is a continuous process of energy conversion and transformation [1]. Many scientists and engineers are in consensus on the irreversible detrimental impacts of fossil fuels such as coal, gas and oil. Additionally, non-renewable primary energy resources are not expected to respond increasing energy demand in the future [2,3]. Therefore, in the last years research, development and investments on renewable and alternative energy systems have been exponentially increased. The oldest and most popular renewable energy resource is known as hydropower. According to the statistics of the year 2018, the total global installed power capacity of renewables (including hydropower) is around $2378 \mathrm{GW}$ [4]. By the end of the same year, the hydropower capacity reported to correspond around half of the total renewable power capacity [4]. Another half of the renewable power is generated from wind, solar, geothermal and ocean power resources which are also known as modern renewables. Wind energy has an exceptional place among other modern renewables with around $591 \mathrm{GW}$ total installed capacity world widely [4].

Aerodynamics and hydrodynamics of fluid environment (water and air) becomes crucially important for renewable power generation. The physical properties of the flow environment have direct effects on the geometric shape of the preferred turbines. Conventional hydroelectric power plants utilize classical type of turbines such as Francis, Pelton or axial flow turbines for energy production [5]. These turbines have either impact or reaction mechanism in which the energy is produced by the hydrodynamic drag and lift forces or a combination of these loads. Conventional hydro turbines concentrate the flow through nozzles in order of generating high capacity of power [6]. Therefore, their efficiency is relatively larger approximating to $90 \%[7,8]$. However, modern wind and hydrokinetic turbines directly convert the kinetic energy of the fluid into electricity without constraining or pressurizing it $[9,10]$. Therefore, they are also called as free flow turbines.

Contemporary free flow turbine technology is greatly based on the conventional hydropower turbines, ship propellers and airplane rotors [11]. However, there is a great deal of difference between the classical and modern turbine technologies. The efficiency of the contemporary wind and hydrokinetic turbines varies at different configurations and it is typically between 0.1 and $0.5[12,13]$. Theoretically, the overall aerodynamic/hydrodynamic efficiency of any free flow turbine cannot exceed $59 \%$, which is also known as Betz limit [14]. This ratio can be increased using a suitable augmentation structure to pressurize the fluid flow around the propeller $[15,16]$.

Free flow wind and hydrokinetic turbine technology is mainly classified based on orientation of the central shaft in which the propeller rotates around it [17]. These are horizontal axis and vertical axis mechanisms [12]. Majority of commercial scale free flow turbines are oriented to be horizontal axis [18]. The main advantage of horizontal axis systems is delivering higher power coefficients (CP) which can exceed 0.5 [9]. The reason behind having relatively higher efficiency is based on the orientation of blade profiles (which are also called as airfoils or hydrofoils). The twist and pitch distributions of horizontal axis machines prevent aerodynamic stall. However, this case is not valid in vertical axis turbines which are also called as cross flow turbines [19]. These turbines (fixed pitch systems) receive the incoming fluid at an axis which is perpendicular to the central shaft. Additionally, they provide very advantageous power output at turbulent and skewed flow conditions [20]. In these systems, together with the azimuthal position changes, the airfoils experience very high angles of attack, resulting aerodynamic stall thus delivering deteriorating performance. Therefore, the typical efficiency of vertical axis machines becomes around 0.1-0.35 [12,21].

Cross flow turbines have different configurations such as, straight bladed (H-shaped) Darrieus turbines [22], Gorlov helical turbines [23], troposkien [24], Achard [25] and spherical turbines [26, 27], all having vertical axis mechanism. Together with delivering lower efficiency rates, they have several advantages over the horizontal axis schemes. They do not need yaw regulation mechanisms having advantage of converting the fluid energy at any direction, even at the reversal currents. Also, simplicity of production and the configuration of generator above the water level are among the other advantages of cross flow turbines [28].

$\mathrm{H}$-shaped Darrieus turbines are known as the most simple and one of the oldest configurations of cross flow machines [29]. The first Darrieus type of turbine design has been proposed by French engineer Darrieus to harness wind energy [1]. These systems have typically 3-5 blades in which the airfoils are oriented to have identical angle of attack along the blades' longitudinal direction without 
having any helicity or twist angle. The blades are connected to the central shaft using suitable type of struts. Although having extensive amount of research on the aerodynamics of Darrieus turbines, their performance is still complicated due to especially dynamic stall problem.

Bachant and Wosnik [30] investigated the near-wake region of the cross flow turbines by experimental analyses and remarked the need of parameterized engineering models for accurately prediction of near-wake physics of cross flow turbines. Dabbagh and Yuce [31] investigated and compared the performance of straight bladed and vertical hydrokinetic turbines using computational tools. It has been reported that, helical turbines are more efficient than the same sized H-shaped Darrieus turbines in terms of power coefficient, especially at high tip speed ratios (TSR). Kirke [32] analyzed the effect of duct around the helical and straight bladed Darrieus turbines concluding that, the power output can be increased by a factor up to 3 using a suitable type of diffuser. Also, straight bladed turbines experienced to have violent vibrations due to high dynamic loads. It is also noted that, turbine shaking problem is greatly solved by using helical type of blades. Kirke and Lazauskas [28] reported the main limitations of fixed pitch Darrieus turbines. They noted that, the efficiency can be increased and vibration and shaking problems which are encountered in H-shaped classical Darrieus systems can be resolved using an active pitch mechanism which will also increase the complexity and cost as a disadvantage. Cheng et al. [33] provided computational analyses on the aerodynamic behavior of helical cross flow turbines. It is reported that, helical systems exhibit better aerodynamic performance and less noise emission rates comparing to the straight bladed machines. Mohamed [1] investigated the performance of straight bladed Darrieus turbines employing different airfoil shapes (both symmetric and non-symmetric) using 2D computational fluid dynamics simulations for maximizing the power output. It has been reported that, the performance can be substantially increased using suitable type of blade section. Balduzzi et al. [20] investigated the energetic sustainability of $\mathrm{H}$-shaped Darrieus turbines for the rooftop installation of a building at different wind profiles and skew employing a computational approach. They reported around $12 \%$ energy increase can be attained at skew angles of $15-35^{\circ}$. Longhuan et al. [34] analyzed the experimental performance of the Darrieus turbines at different solidity, blade profile, pitch angle and aspect ratio distributions. Importance of the blade's span angle on the selfstarting capability of the turbine is outlined. The unsteady behavior of the Darrieus turbine aerodynamics have been remarked by Rezaeiha et al. [35]. The effect of blade camber and curvature on the unsymmetrical blade profiles used in Darrieus turbines has been investigated by Sengupta et al. [36]. The experimental performance of Darrieus turbines have been investigated by Battisti et al. [37]. Finally, low speed wind tunnel performance of $\mathrm{H}$-shaped Darrieus turbines were analyzed by Scungio et al. [38].

Majority of the abovementioned studies examine the performance of Darrieus turbines at different geometrical and dynamic configurations using mainly computational and experimental tools. Experimental studies are rather time consuming and expensive works. Similarly, the unsteady behavior of Darrieus turbines at various azimuthal position of the blades due to the stall problem have been reported in many studies [33, 39-41]. The need for parametric engineering models have also been outlined in the previous studies [30]. Therefore, detailed study of various geometrical and dynamic conditions of Darrieus turbines using numerical algorithms which employ the physical models generated for the vertical axis turbines (Actuator disk, BEM and MST and DMST theories) becomes substantially important in order of providing a practical approach [42]. The main objective of this study is to analyze Darrieus turbines at different geometrical and dynamic configurations and to investigate the effect of airfoil selection, thickness, solidity, number of blades, chord length and helicity on the performance of straight bladed Darrieus turbines using numerical QBlade algorithm. Various different configurations have been tested, their performances were compared and the optimum design specifications were outlined to contribute Darrieus turbine design studies. The main findings were discussed with existing literature studies in details.

\section{Materials and Method}

\subsection{QBlade}

QBlade is an open source code that has been developed for horizontal and vertical wind turbine design analyses and simulations by the Hermann Föttinger Institute (Berlin) [43]. The algorithm have capability of extrapolating the airfoil polars through $360^{\circ}$, interface for inputting turbine's geometrical parameters, 
calculating the rotor's performance at various dynamic conditions and estimating the overall performance using the DMST (Double Multiple Stream Tube Theory) [44]. The performance of twodimensional blade sections are evaluated using the XFOIL software which is known as the most popular airfoil panel code [45, 46]. Turbine blades are defined to be combination of a number of airfoil segments having specified span lengths. Geometric modifications such as twist, helicity, chord length, azimuthal angle, etc. are defined for each of the blade segments. Then, the dynamic properties of flow such as, cutin and cut-out velocities, tip speed ratio, free stream speed, etc. are defined [43]. QBlade algorithm's basic working mechanism is illustrated in Figure 1.

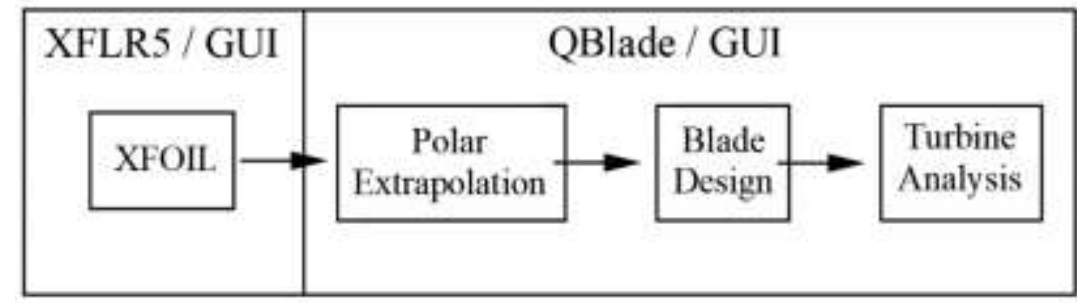

Figure 1. QBlade algorithm running mechanism (modified from [43])

Validation of the QBlade algorithm had been provided by [43] using the experimental [47] and numerical outputs of double multiple stream tube theory. Satisfying results were reported exhibiting quite similar behavior with the numerical DMST code that is originally proposed by Parachivoiu [48] until the peak power. It should be noted that, QBlade shows slightly higher results compare to the Parachivoiu's double multiple stream tube model, after the rated power. Also, QBlade algorithm has been validated with Sandia turbine [47] having $17 \mathrm{~m}$ longitudinal length delivering effectual results and providing good agreement compare to the experimental analyses [43] (Figure 2).

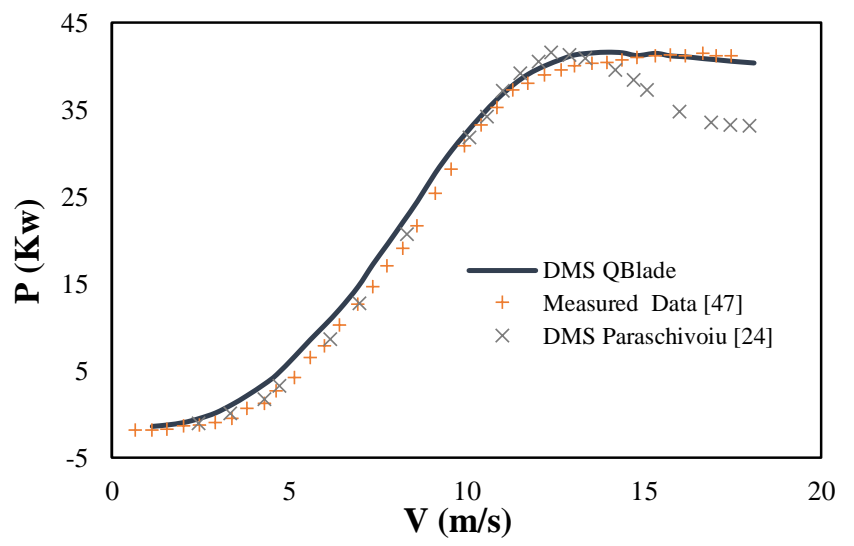

Figure 2. Validation of QBlade algorithm (Modified from [49])

\subsection{Vertical axis turbine theory}

The extractable power of a free-flowing stream inside a cross sectional area of $A$ is given in Equation 1. It should be noted that, the power output of any free flow turbine is proportional with the cube of free stream speed $\left(U_{\infty}\right)$. Thus, velocity regime of the turbine domain becomes substantially important. On the other hand, free flow devices can harness a certain amount of energy inside the flow domain based on their efficiency $(\eta)$ which is an output of rotor geometry and aerodynamic/hydrodynamic properties of flow around the turbine blades.

$$
P=0.5 \rho A U_{¥}{ }^{3} \eta
$$

where, $P$ is the extractable power, $\rho$ is the fluid's density, $A$ is the cross-sectional area normal to the free stream velocity, $U_{\infty}$ is the free stream speed and $\eta$ is the overall aerodynamic and mechanical efficiency of the rotor.

The free stream speed $\left(U_{\infty}\right)$ is modified by aerodynamic induction factors [48] and converted 
into local velocity components in $\mathrm{x}$ and $\mathrm{y}$ directions (Figure 3 ). A resultant velocity is obtained $\left(U_{r}\right)$ from the combination of Cartesian velocity components and the rotational velocity of the turbine blades $\left(U_{\theta}\right)$ [50]. Aerodynamic (lift and drag) forces generated on the blade sections are formed as a result of the relative velocity component acted at an angle of attack $(\alpha)$ which is the angle between the airfoil chord and applied velocity vector $\left(U_{r}\right)$.

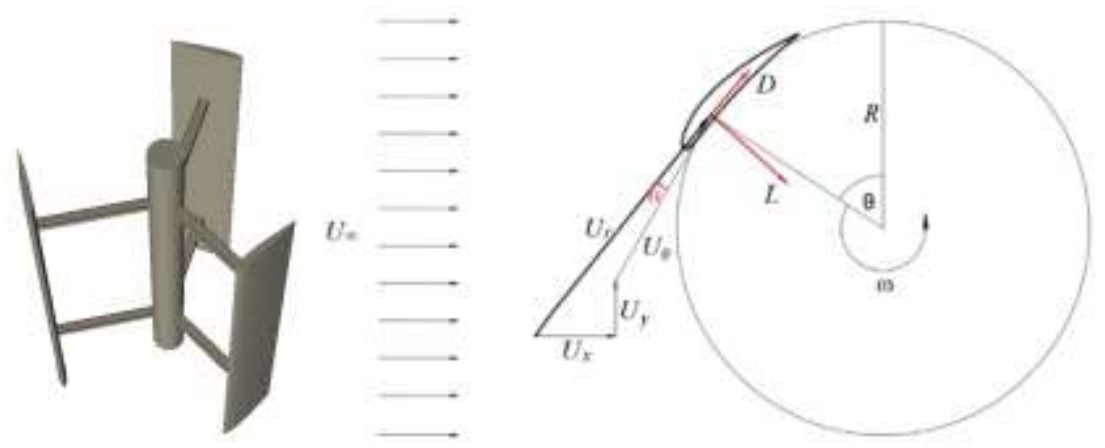

Figure 3. A conceptual Darrieus turbine and velocity vectors and loads generated on the longitudinal rotor section (Modified from [50])

Accordingly, lift and drag forces generated on each blade section can be defined as follows;

$$
\begin{aligned}
L & =\frac{1}{2} \rho U_{r}{ }^{2}(b c) C_{L} \\
D & =\frac{1}{2} \rho U_{r}{ }^{2}(b c) C_{D}
\end{aligned}
$$

where, $L$ is the lift force, $D$ is the drag force, $U_{r}$ is the relative velocity vector, $b$ is the span length of each blade segment, $c$ is the chord length of the blade profiles, $C_{D}$ is the coefficient of drag and $C_{L}$ is the coefficient of lift of employed airfoil sections.

During the rotation, after $180^{\circ}$ azimuth angle, the blade sections are exposed to negative angle of attack values. The direction of the lift force is varied in this case. However, the resultant lift force is always produces positive torque at a unit length of the blade [50]. The blade's angle of attack can be written as a function of induced velocity and relative velocity at different azimuthal position as [51];

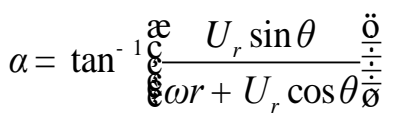

Torque is the most important parameter that is required for power production of rotor. Resultant torque per unit length of the blade can be written as a function of lift and drag forces and turbine's geometrical parameters as follows [50];

$Q=N R(L \sin a-D \cos a)$

where, $Q$ is the total torque, $N$ is he number of blades, $R$ is the rotor radius.

Detailed illustration of one dimensional momentum theory, blade element momentum (BEM), double actuator disk concept and double multiple stream tube (DMS) theories are provided by Muratoglu [52], Demir [53], Consul [50] and Paraschivoiu [24, 54].

Tip speed ratio and solidity terms are also important for characterizing the turbine's dynamic and geometrical conditions. Both parameters are frequently used by many of the literature studies as a common criterion for comparison among the generated designs. Tip speed ratio $(T S R, \lambda)$ is known as dimensionless parameter that shows the ratio of the blades' tangential velocity to the free stream velocity (Equation 6). On the other hand, solidity $(\sigma)$ is parameter of number of blades, chord length and radius which is defined as the ratio of the total blade planform area to the swept area (Equation 7).

$\lambda=\frac{\omega R}{U_{¥}}$ 
$\sigma=\frac{c N}{2 R}$

where, $\lambda$ is the tip speed ratio, $\omega$ is the rotational speed, $R$ is the turbine radius, $U_{\infty}$ is the free stream velocity, $\sigma$ is the rotor solidity, $c$ is the chord length, $N$ is the number of blades.

\section{Result and Discussion}

\subsection{Investigation the Effect of Airfoil Selection on the Performance}

Selecting a suitable airfoil shape is the most important parameter to maximize turbine efficiency [55]. In this section, various airfoils that are frequently employed in $\mathrm{H}$-shaped Darrieus turbines are compared. The geometrical illustration of symmetrical and asymmetrical airfoils that are analyzed in this study are given Figure 4 . Their aerodynamic performance $\left(C_{L^{-}} \alpha\right.$ and $C_{L} / C_{D^{-}} \alpha$ curves $)$ which is calculated by XFOIL software are provided in Figure 5. Also, numerical QBlade analysis outputs of the straight bladed Darrieus turbines that are designed using these airfoils are reported in Figure 6.

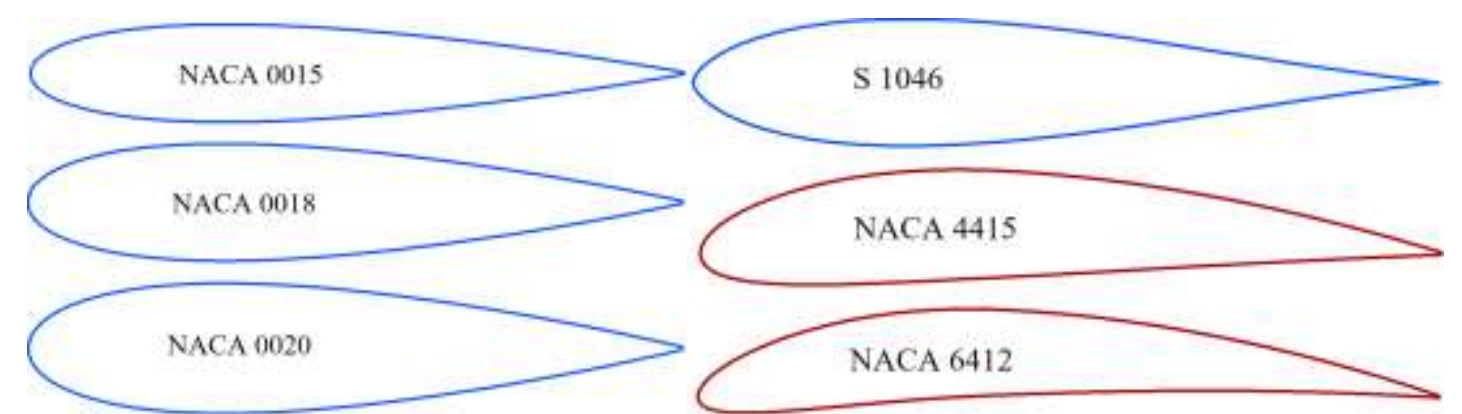

Figure 4. Geometric illustration of symmetrical and asymmetrical airfoils analyzed in this study
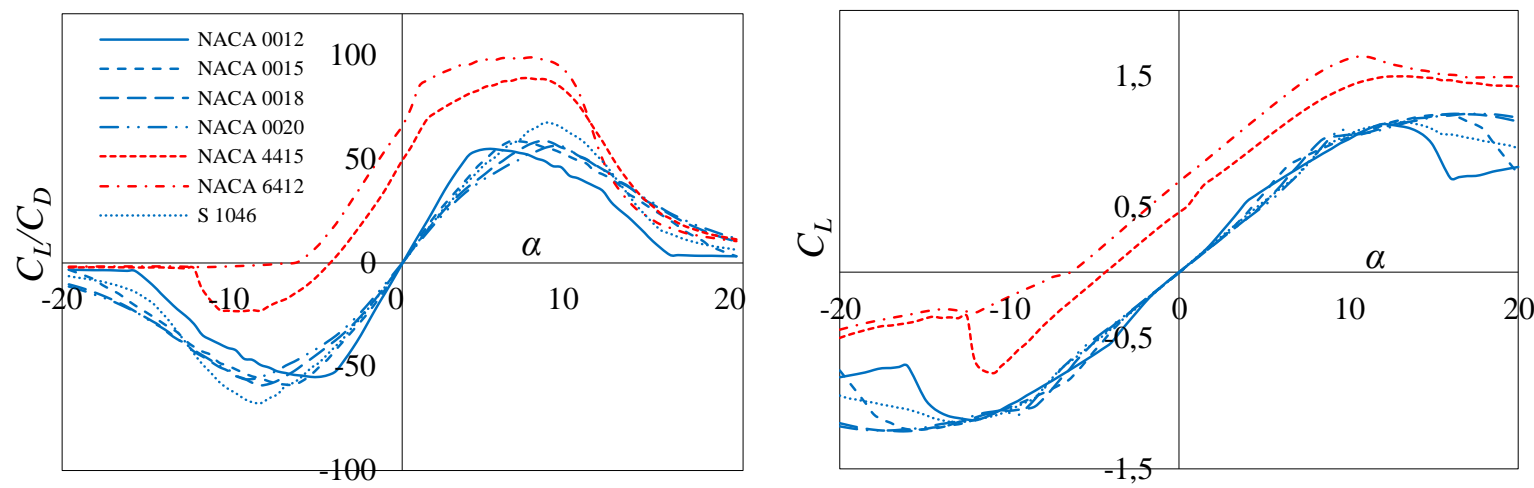

Figure 5. Performance analysis of some symmetrical and asymmetrical airfoils $\left(\mathrm{Re}=0.33 \times 10^{6}\right)$

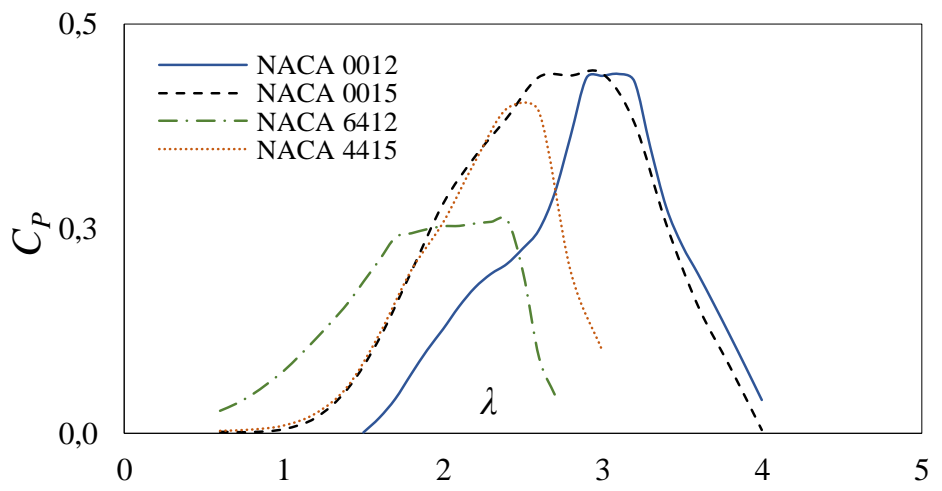

Figure 6. $\mathrm{H}=$ Darrieus turbine performance comparison using symmetrical and asymmetrical airfoils $(\mathrm{H}=1.5 \mathrm{~m}$, $\mathrm{R}=0.5 \mathrm{~m}, \mathrm{c}=0.2 \mathrm{~m}, \mathrm{~N}=3$ ) 
Many studies report that, blade profiles having symmetrical cross-section perform much better than asymmetrical profiles at negative angles of attack $[50,56]$. Although asymmetrical blade sections have relatively higher lift/drag performance in positive angles of attack, their performance deteriorates in negative $\alpha$ values relative to symmetrical sections (Figure 5). Accordingly, superior performance of Darrieus turbines modeled using symmetrical turbines can be clearly identified in Figure 6. In this study, turbines having the symmetrical airfoils of NACA 0012 and NACA 0015 represented considerably higher power coefficient than asymmetrical airfoils of NACA 6412 and NACA 4415.

The type of employed airfoil which is mainly characterized by per cent thickness is another important design criterion for high performance. There have been different literature studies investigating the effect of thickness on the $C_{P}-T S R$ curve. Subramanian et al. [57] compared the performances of blade profiles having different \% thicknesses for vertical axis turbines and reported that, thinner airfoils such as NACA 0012 have higher $C_{P}$ at high TSR values while, thick profiles such as NACA 0030 perform better at low TSR values $(<2)$. Thus, thinner airfoils have the $C_{P}$-TSR curve shifted to the right-hand side. A similar consequence has also been observed by Rezaeiha et al. [58]. Mohamed [1] investigated the performance of straight bladed Darrieus turbines made of various different airfoils having both symmetric and non-symmetric body using CFD methods reporting that, symmetric S-1046 section delivered maximum power coefficient. Similarly, Brinck and Jeremejeff [59] analyzed H-shaped Darrieus turbines using DMST model and proposed that S-1046 section delivered highest performance with unfavorable oscillating torque. Again, Feng et al. [56] highlighted high performance of S-1046 airfoil relative to non-symmetrical S809 profiles. In the present study, similar to Mohamed [1], Brinck and Jeremejeff [59] and Feng et al. [56], the maximum $C_{P}$ was obtained using S1046 airfoils with slight differences. However, maximization solely the power coefficient would not be sufficient especially in stall regulated turbines. Delivering high $C_{P}$ at relatively a wide range of TSR is also a desired property. Also, similar to Subramanian et al. [57] and Rezaeiha et al. [58], thicker blade profiles represented better performance at low TSR values. Consequently, in this study, NACA 0020 blade profile has been found to be more suitable for straight bladed vertical axis turbines because of especially its high performance in low TSR values and having wider TSR range. Also, the present study highlights that, similar to Brusca et al. [60] and Subramanian et al. [57], Darrieus turbines designed from symmetrical airfoils should be operated in the TSR range of 2-3 (Figure 7).

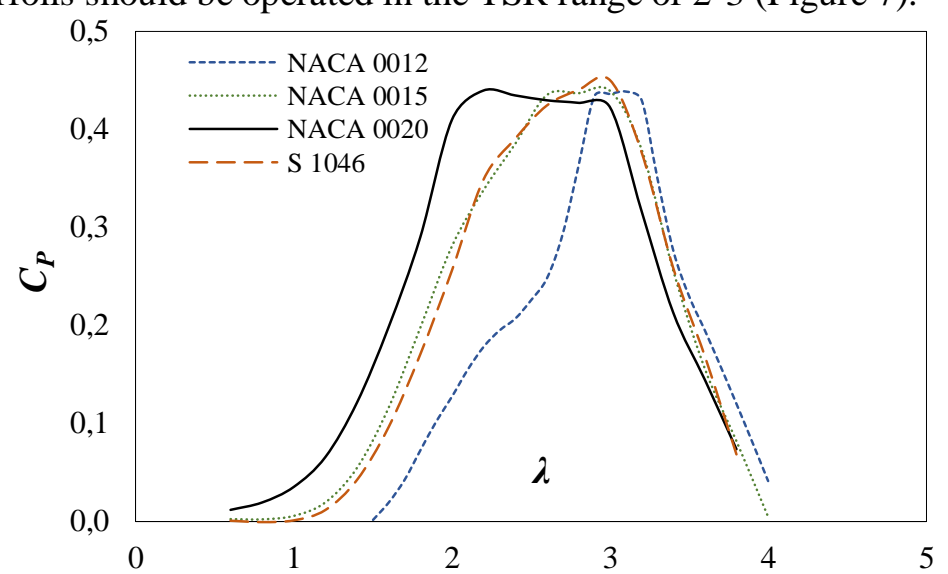

Figure 7. Performance comparison of symmetrical airfoils $(\mathrm{H}=1.5 \mathrm{~m}, \mathrm{r}=0.5 \mathrm{~m}, \mathrm{c}=0.2 \mathrm{~m}, \mathrm{~N}=3)$

\subsection{Effect of Solidity, Number of Blades and Chord Length}

Solidity varies as a function of turbine diameter, number of blades and chord length (Equation 7). In literature, the effect of solidity on VAWT has been investigated in two different ways; depending on the number of blades and the length of the chord. Qamar and Janajreh [61] tested the effect of solidity on the performance and reported that, the maximum performance is obtained at $N=3$ and $\sigma=0.45$. Similarly, Delafin et al. [62] proposed that, the maximum power coefficient is proportional with the number of blades at the same chord length. Again, Subramanian et al. [57] stated that the maximum power coefficient is obtained at lower TSR values and higher number of blades. In the present study, we compared Darrieus turbine performance for different blade numbers and chord lengths (Figure 8 and 9). We obtained that, the maximum power coefficient characteristics are quite similar except some 
slight differences. Four-bladed turbine represented the maximum power coefficient in this study. However, as the number of blades increases, the TSR range delivering maximum power coefficient become narrower. On the other hand, similar to Delafin et al. [62], Qamar and Janajreh [61], Rezaeiha et al. [58], we observed that, increasing blade number shifts $C_{P}$-TSR curve to the left side (Figure 9).

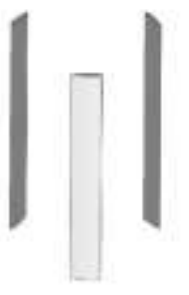

$\mathrm{N}=3$

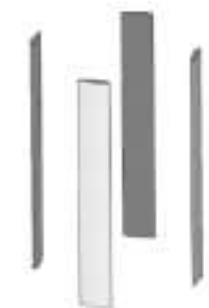

$\mathrm{N}=4$

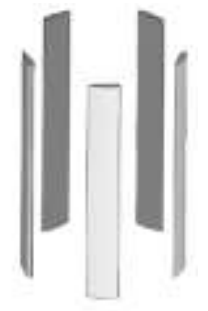

$\mathrm{N}=5$

Figure 8. Different number of blades modeled in this study

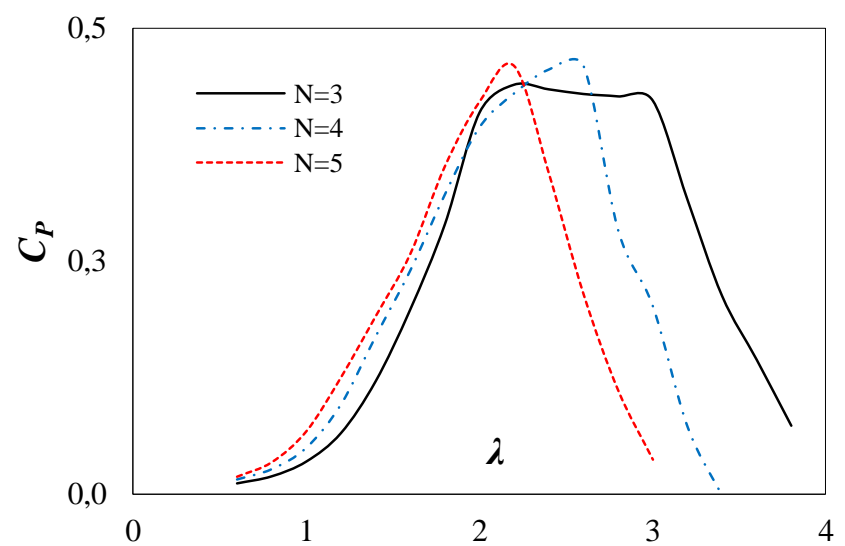

Figure 9. Comparison of blade number on the performance of Darrieus turbines $(\mathrm{H}=1.5 \mathrm{~m}, \mathrm{R}=0.5 \mathrm{~m}, \mathrm{c}=0.2 \mathrm{~m})$

Eboibi et al. [63] reported the better performance at $\sigma=0.34$ relative to $\sigma=0.26$. Rezaeiha et al. [58] stated that the maximum power coefficient increases when solidity increases up to 0.36 . On the other hand, Roh and Kang [64] highlighted the maximum $C_{P}$ is increased up to a solidity number of 0.3 . Accordingly, in this study the performance at different chord lengths of NACA 0020 section $(\mathrm{N}=3)$ is compared (Figure 10). It can be observed that similar to Rezaeiha et al. [58], Roh ve Kang [64] and Eboibi et al. [63] the maximum $C_{P}$ increased until a chord length of $\mathrm{c}=0.12 \mathrm{~m}(\sigma=0.36)$. However, further increments of chord length are observed to have reduced $C_{P}$. Also, the optimum TSR range delivering high performance expands which is a desired property. At low TSR values, the turbine performs better as the chord length increases parallel to the Sheikh [65]. At higher TSR values, the performance deteriorates as the cord length increases which is also supported by Winchester and Quayle [66].

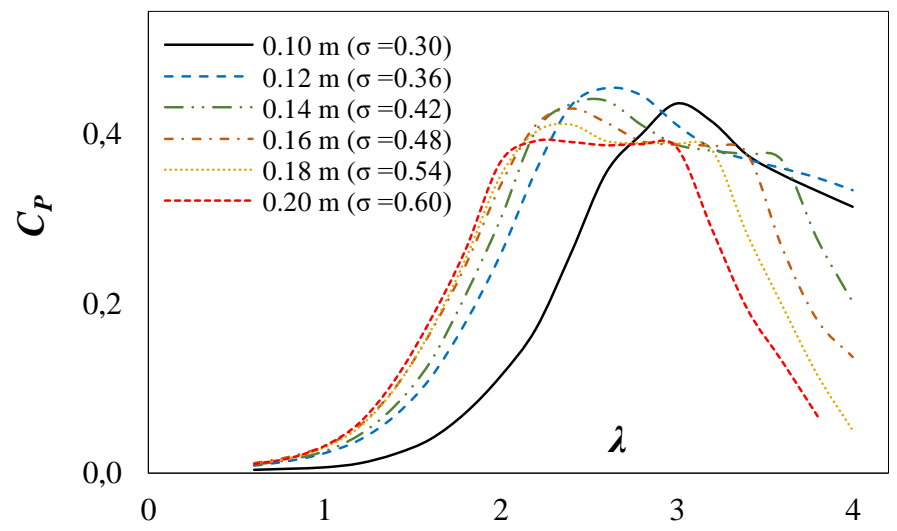

Figure 10. Effect of chord length on the performance of Darrieus turbines $(H=1.5 \mathrm{~m}, \mathrm{R}=0.5 \mathrm{~m}, \mathrm{~N}=3)$ 


\subsection{Effect of Blade Helicity}

The first helical turbine was developed to solve the vibration problems of Darrieus turbines [9]. These turbines are formed by rotating the blades around their longitudinal axes to give a helical structure. Several studies $[67,68]$ proposed that, straight bladed turbine deliver higher power than helical turbines. However, Al-Dabbagh and Yuce [31] found the efficiency of helical turbines to be slightly higher. Nevertheless, according to Battisti et al. [69] maximum power coefficient of both type of turbines are very close to each other, where the helical turbine showed high performance in a wider TSR range. It can be said that, existing literature studies are not agreed on positive contributions of the helicity for power maximization. However, reduced load fluctuations and prolonged life of helical turbines are a topic of common estimates. In the present study, three different turbines have been designed at different helicity angles $(0,45$, and 60 degrees, Figure 11) and their performance is compared using DMST method. Parallel to existing works, the power coefficients and average torques of straight and helical bladed turbines were found to be the same. However, when the instantaneous torque graph is analyzed (Figure 12), the torque oscillation of the helical turbines is observed to be lower than that of the straight bladed turbines parallel to the studies of Niblick [70], Marsh et al. [67], Moghimi et al. [68] and Winchester and Quayle [66].
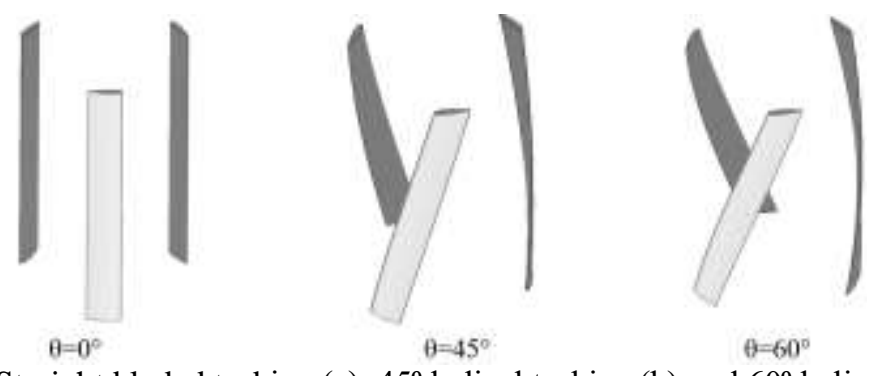

Figure 11. Straight bladed turbine (a), $45^{\circ}$ helical turbine (b) and $60^{\circ}$ helical turbine (c)

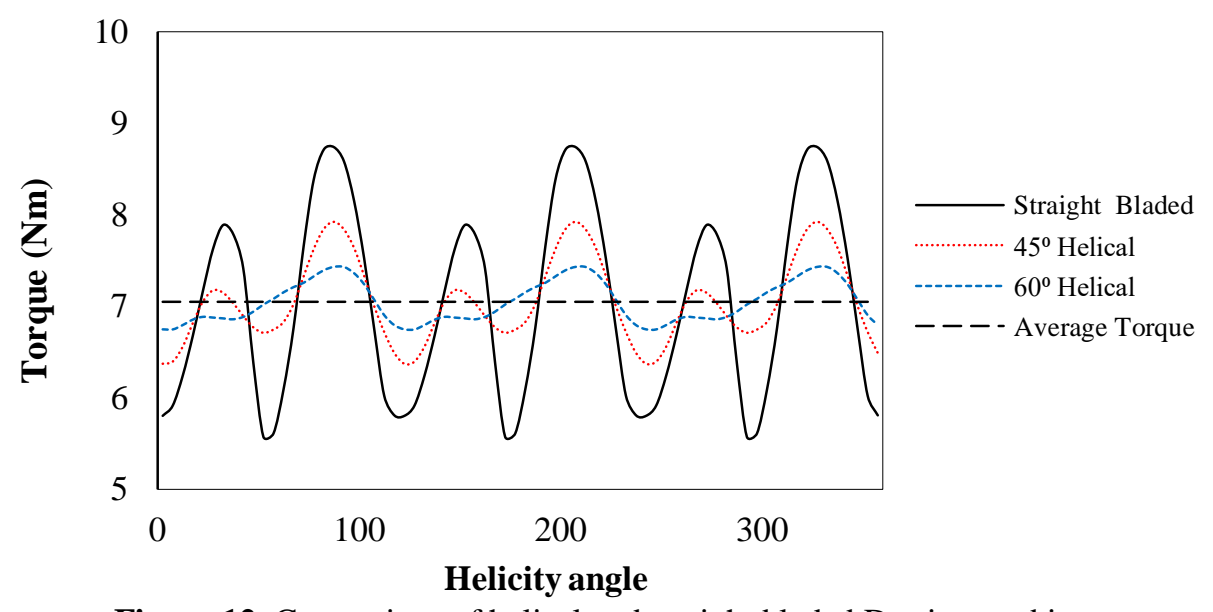

Figure 12. Comparison of helical and straight bladed Darrieus turbine

Helical turbine blade segments are exposed to various different angles of attack at an instantaneous timestep. Nevertheless, each blade of straight bladed Darrieus turbines experience constant angle of attack at a specific azimuthal position. Therefore, torque fluctuations are reduced in helical turbines compare to the straight bladed designs. Consequently, in parallel to the previous works the basic findings of this study outline that, straight bladed and helical turbines generally perform similar in terms of power maximization, where helical turbines represented less torque oscillations.

\section{Conclusion}

In this study, the effect of airfoil type, number of blades, chord length, solidity and helicity which are the most important design parameters for the performance of vertical axis turbines have been investigated using QBlade code which employs DMST algorithm. Accordingly, vertical axis turbines 
with symmetrical blade profiles provide optimum performance in the TSR range of 2-3. Among symmetrical blade sections, the NACA 0020 profile is found to be more suitable for vertical axis turbines. As the number of blades increases, the range of TSR in which the turbine is efficient is narrowed. Three blades have been found to be optimum for sufficient performance and reduced cost in straight bladed vertical axis turbines. At higher chord length and solidity values, the TSR value delivering maximum $C_{P}$ is decreased. A concrete relationship showing the effect of helicity on $C_{P}$ has not been attained. However, torque oscillations are observed to be reduced at increased helicity angles.

\section{Authors' Contribution}

A.M conceived and supervised the study, wrote the manuscript and M.S.D., performed the numerical analyses and contributed to discussions.

\section{Statement of Conflicts of Interest}

The authors have no competing interests to declare.

\section{Statement of Research and Publication Ethics}

The authors complied with research and publication ethics. This article does not contain any studies involving animals or human participants performed by any of the authors.

\section{References}

[1] Mohamed M.H. 2012. Performance investigation of H-rotor Darrieus turbine with new airfoil shapes. Energy, 47 (1): 522-530.

[2] Mejbri A., Haddou S., Rejeb J.B. 2014. Renewable energy, fossil fuels and economic development: Evidence from the Middle East and North African countries. The Journal of Energy and Development, 40 (1/2): 209-228.

[3] Martins F., Felgueiras C., Smitková M. 2018. Fossil fuel energy consumption in European countries. Energy Procedia, 153: 107-111.

[4] REN21. 2019. Renewables 2019 Global Status Report.

[5] Çengel Y.A., Cimbala J.M.. 2006. Fluid mechanics: fundamentals and applications. Fluid Mechanics: With Problems and Solutions, and an Aerodynamic Laboratory, New York.

[6] Williamson S.J., Stark B.H., Booker J.D. 2014. Low head pico hydro turbine selection using a multi-criteria analysis. Renewable Energy, 61: 43-50.

[7] Okot D.K. 2013. Review of small hydropower technology. Renewable and Sustainable Energy Reviews, 26: 515-520.

[8] Elbatran A.H., Yaakob O.B., Ahmed Y.M., Shabara H.M. 2015. Operation, performance and economic analysis of low head micro-hydropower turbines for rural and remote areas: A review. Renewable and Sustainable Energy Reviews, 43: 40-50.

[9] Yuce M.I., Muratoglu A. 2015. Hydrokinetic energy conversion systems: A technology status review. Renewable and Sustainable Energy Reviews, 43: 72-82.

[10] Muratoglu A., Yuce M.I. 2017. Design of a River Hydrokinetic Turbine Using Optimization and CFD Simulations. Journal of Energy Engineering, 143 (4).

[11] Batten W.M.J., Bahaj A.S., Molland A.F. 2006. Chaplin J.R., Hydrodynamics of marine current turbines. Renewable Energy, 31 (2) : 249-256.

[12] Aslam Bhutta M.M., Hayat N., Farooq A.U., Ali Z., Jamil S.R., Hussain Z. 2012.Vertical axis wind turbine - A review of various configurations and design techniques. Renewable and Sustainable Energy Reviews, 16 (4) : 1926-1939.

[13] Tummala A., Velamati R.K., Sinha D.K., Indraja V., Krishna V.H. 2016. A review on small scale wind turbines. Renewable and Sustainable Energy Reviews, 56: 1351-1371.

[14] Gorban A.N., Gorlov A.M., Silantyev V.M. 2001. Limits of the Turbine Efficiency for Free Fluid Flow. Journal of Energy Resources Technology, 123 (4) : 311-317.

[15] Chen L., Ponta F.L., Lago L.I. 2011. Perspectives on innovative concepts in wind-power 
generation. Energy for Sustainable Development, 15 (4) : 398-410.

[16] Shonhiwa C., Makaka G. 2016. Concentrator Augmented Wind Turbines: A review. Renewable and Sustainable Energy Reviews, 59: 1415-1418.

[17] Muratoglu A. 2018. A review on alternative hydropower production methods. Journal of Engineering and Tecnology, 2: 21-28.

[18] Khan M.J., Bhuyan G., Iqbal M.T. 2009. Quaicoe J.E., Hydrokinetic energy conversion systems and assessment of horizontal and vertical axis turbines for river and tidal applications: A technology status review. Applied Energy, 86 (10) : 1823-1835.

[19] Forbush D., Cavagnaro R.J., Polagye B. 2019. Power-tracking control for cross-flow turbines. Journal of Renewable and Sustainable Energy, 11 (1): 014501.

[20] Balduzzi F., Bianchini A., Carnevale E.A., Ferrari L., Magnani S.2012. Feasibility analysis of a Darrieus vertical-axis wind turbine installation in the rooftop of a building. Applied Energy: 97 921-929.

[21] Kim D., Gharib M., Efficiency improvement of straight-bladed vertical-axis wind turbines with an upstream deflector. Journal of Wind Engineering and Industrial Aerodynamics, 115: 48-52, 2013.

[22] Raciti Castelli M., Ardizzon G., Battisti L., Benini E., Pavesi G. 2010. Modeling Strategy and Numerical Validation for a Darrieus Vertical Axis Micro-Wind Turbine, 409-418.

[23] Gorlov M. 1995. The helical turbine: A new idea for low-head hydro. Hydro Review, 14 (5).

[24] Paraschivoiu I. 2002. Wind turbine design: with emphasis on Darrieus concept. Polytechnic International Press.

[25] Bernad S., Georgescu A., Georgescu S.-C., Susan-Resiga R., Anton I. 2008. Flow investigations in Achard turbine. Proceedings of the Romanian Academy, 9 (2).

[26] Gorlov A.M. 2012. Universal spherical turbine with skewed axis of rotation. https://patents.google.com/patent/US20120070294A1/en (Access Date: 26.01.2019)

[27] Mosbahi M., Ayadi A., Mabrouki I., Driss Z., Tucciarelli T., Abid M.S. 2019. Effect of the Converging Pipe on the Performance of a Lucid Spherical Rotor. Arabian Journal for Science and Engineering, 44 (2): 1583-1600.

[28] Kirke B.K., Lazauskas L. 2011. Limitations of fixed pitch Darrieus hydrokinetic turbines and the challenge of variable pitch. Renewable Energy, 36 (3): 893-897.

[29] Kiho S., Shiono M., Suzuki K. 1996. The power generation from tidal currents by darrieus turbine. Renewable Energy, 9 (1-4): 1242-1245.

[30] Bachant P., Wosnik M. 2015. Characterising the near-wake of a cross-flow turbine. Journal of Turbulence, 16 (4): 392-410.

[31] Al-Dabbagh M.A., Yuce M.I. 2018. Simulation and Comparison of Helical and Straight-bladed Hydrokinetic Turbines. International Journal of Renewable Energy Research (IJRER), 8 (1): 504513.

[32] Kirke B.K. 2011. Tests on ducted and bare helical and straight blade Darrieus hydrokinetic turbines. Renewable Energy, 36 (11): 3013-3022.

[33] Cheng Q., Liu X., Ji H.S., Kim K.C., Yang B. 2017. Aerodynamic Analysis of a Helical Vertical Axis Wind Turbine. Energies, 10 (4).

[34] Du L., Ingram G., Dominy R.G. 2019. Experimental study of the effects of turbine solidity, blade profile, pitch angle, surface roughness, and aspect ratio on the H-Darrieus wind turbine self-starting and overall performance. Energy Science \& Engineering. https://doi.org/10.1002/ese3.430.

[35] Rezaeiha A., Montazeri H., Blocken B. 2019. On the accuracy of turbulence models for CFD simulations of vertical axis wind turbines. Energy, 180: 838-857.

[36] Sengupta A.R., Biswas A., Gupta R. 2019. Comparison of low wind speed aerodynamics of unsymmetrical blade H-Darrieus rotors-blade camber and curvature signatures for performance improvement. Renewable Energy, 139: 1412-1427.

[37] Battisti L., Persico G., Dossena V., Paradiso B., Raciti Castelli M., Brighenti A., Benini E. 2018. Experimental benchmark data for $\mathrm{H}$-shaped and troposkien VAWT architectures. Renewable Energy, 125: 425-444.

[38] Scungio M., Arpino F., Focanti V., Profili M., Rotondi M. 2016. Wind tunnel testing of scaled models of a newly developed Darrieus-style vertical axis wind turbine with auxiliary straight blades. Energy Conversion and Management, 130: 60-70.

[39] Mohamed M.H., Dessoky A., Alqurashi F. 2019. Blade shape effect on the behavior of the H-rotor 
Darrieus wind turbine: Performance investigation and force analysis. Energy, 179: 1217-1234.

[40] Carrigan T.J., Dennis B.H., Han Z.X., Wang B.P. 2012. Aerodynamic Shape Optimization of a Vertical-Axis Wind Turbine Using Differential Evolution. ISRN Renewable Energy: 1-16.

[41] Ghasemian M., Ashrafi Z.N., Sedaghat A. 2017. A review on computational fluid dynamic simulation techniques for Darrieus vertical axis wind turbines. Energy Conversion and Management, 149: 87-100.

[42] Muratoğlu A., Demir M.S. 2019. Numerical analysis of a straight bladed vertical axis Darrieus wind turbine: Verification of DMS algorithm and QBlade code. European Journal of Technic, 9 (2): 195-208.

[43] Marten D., Wendler J., Pechlivanoglou G., Nayeri C.N., Paschereit C.O. 2013. Qblade: An Open Source Tool for Design and Simulation of Horizontal and Vertical Axis Wind Turbines. International Journal of Emerging Technology and Advanced Engineering, 3 (3): 264-269.

[44] Qblade. 2018. Wind turbine design and simulation. Hermann Föttinger Institute of TU Berlin.

[45] Drela M. 2013. Xfoil: Subsonic Airfoil Development System, MIT.

[46] Morgado J., Vizinho R., Silvestre M.A.R., Páscoa J.C. 2016. XFOIL vs CFD performance predictions for high lift low Reynolds number airfoils. Aerospace Science and Technology, 52: 207-214.

[47] Worstell M.H. 1981. Aerodynamic Performance of the DOE/Sandia 17-m-Diameter Vertical-Axis Wind Turbine. Journal of Energy, 5 (1): 39-42.

[48] Paraschivoiu I., Delclaux F. 1983. Double multiple streamtube model with recent improvements (for predicting aerodynamic loads and performance of Darrieus vertical axis wind turbines). Journal of Energy, 7 (3): 250-255.

[49] Marten D., Wendler J., Pechlivanoglou G., Nayeri C.N., Paschereit C.O. 2013. Development and Application of a Simulation Tool For Vertical and Horizontal Axis Wind Turbines. Proceedings of the ASME Turbo Expo, 8 (June).

[50] Consul C.A. 2011. Hydrodynamic Analysis of a Tidal Cross-Flow Turbine, Oxford.

[51] Bachant P. 2011. Experimental investigation of helical cross-flow axis hydrokinetic turbines, including effects of waves and turbulence. University of New Hampshire, M.Sc. thesis, 122 p, Durham.

[52] Muratoglu A. 2014. Design and simulation of a riverine hydrokinetic turbine. Ph.D. thesis, University of Gaziantep, Institute of Natural and Applied Sciences, 212 p, Gaziantep.

[53] Demir M.S. 2019. Design and CFD analyses of a spherical hydrokinetic turbine for energy production in gravity water transmission pipelines. M.Sc. thesis, Batman University, Institute of Natural and Applied Sciences, 72 p, Batman.

[54] Paraschivoiu I. 1982. Aerodynamic loads and performance of the Darrieus rotor. Journal of Energy, $6(6): 406-412$.

[55] Hashem I., Mohamed M.H. 2018. Aerodynamic performance enhancements of H-rotor Darrieus wind turbine. Energy, 142: 531-545.

[56] Feng F., Zhao S., Qu C., Bai Y., Zhang Y., Li Y.2018. Research on Aerodynamic Characteristics of Straight-Bladed Vertical Axis Wind Turbine with S Series Airfoils. International Journal of Rotating Machinery. https://doi.org/10.1155/2018/8350243.

[57] Subramanian A., Yogesh S.A., Sivanandan H., Giri A., Vasudevan M., Mugundhan V., Velamati R.K. 2017. Effect Of Airfoil and Solidity On Performance Of Small Scale Vertical Axis Wind Turbine Using Three Dimensional CFD Model. Energy, 133: 179-190.

[58] Rezaeiha A., Montazeri H., Blocken B. 2018. Towards optimal aerodynamic design of vertical axis wind turbines: Impact of solidity and number of blades. Energy, 165: 1129-1148.

[59] Brinck D., Jeremejeff N. 2013. The development of a vertical axis tidal current turbine. KTH School of Industrial Engineering and Management. M.Sc. thesis, KTH School of Industrial Engineering and Management, Division of Energy Techhnology, 84 p, Stockholm.

[60] Brusca S., Lanzafame R., Messina M. 2015. Design and performance of a straight-bladed darrieus wind turbine Design and Performance of a Straight-Bladed Darrieus Wind Turbine. International Journal of Applied Engineering Research, 10 (September), 3979-3982.

[61] Qamar S.B., Janajreh I. 2017. A Comprehensive Analysis Of Solidity For Cambered Darrieus VAWTs. International Journal of Hydrogen Energy, 42 (30): 19420-19431.

[62] Delafin P.L., Nishino T., Wang L., Kolios A. 2016. Effect Of The Number Of Blades And Solidity 
On The Performance Of a Vertical Axis Wind Turbine. Journal of Physics: Conference Series, 753 (2).

[63] Eboibi O., Danao L.A.M., Howell R.J. 2016. Experimental Investigation of The Influence of Solidity On The Performance and Flow Field Aerodynamics of Vertical Axis Wind Turbines at Low Reynolds Numbers. Renewable Energy, 92: 474-483.

[64] Roh S.C., Kang S.H. 2013. Effects of a blade profile, the Reynolds number, and the solidity on the performance of a straight bladed vertical axis wind turbine. Journal of Mechanical Science and Technology, 27 (11): 3299-3307.

[65] Sheikh S.R. 2015. Hydrodynamic Design and Optimization of Vertical Axis Water Turbine for Shallow and High Velocity Water Streams of Pakistan. in: UMT National Multidisciplinary Engineering Conference 2015 (NMEC-15), (November), 1-18, 2015. doi:10.13140/RG.2.1.3358.1520.

[66] Winchester J., Quayle S. 2009. Torque Ripple and Variable Blade Force: A Comparison of Darrieus and Gorlov-Type Turbines For Tidal Stream Energy Conversion, in Proceedings of the 8th European Wave and Tidal Energy Conference, 668-676.

[67] Marsh P., Ranmuthugala D., Penesis I., Thomas G. 2015.Numerical investigation of the influence of blade helicity on the performance characteristics of vertical axis tidal turbines. Renewable Energy, 81: 926-935.

[68] Moghimi M., Motawej H. 2020. Developed DMST Model For Performance Analysis and Parametric Evaluation of Gorlov Vertical Axis Wind Turbines. Sustainable Energy Technologies and Assessments, 37. https://doi.org/10.1016/j.seta.2019.100616.

[69] Battisti L., Brighenti A., Benini E., Castelli M.R. 2016. Analysis of Different Blade Architectures on Small VAWT Performance. Journal of Physics: Conference Series, 753 (6).

[70] Niblick A.L. 2012. Experimental and Analytical Study of Helical Cross-Flow Turbines for a Tidal Micropower Generation System. University of Washington, Washington. 


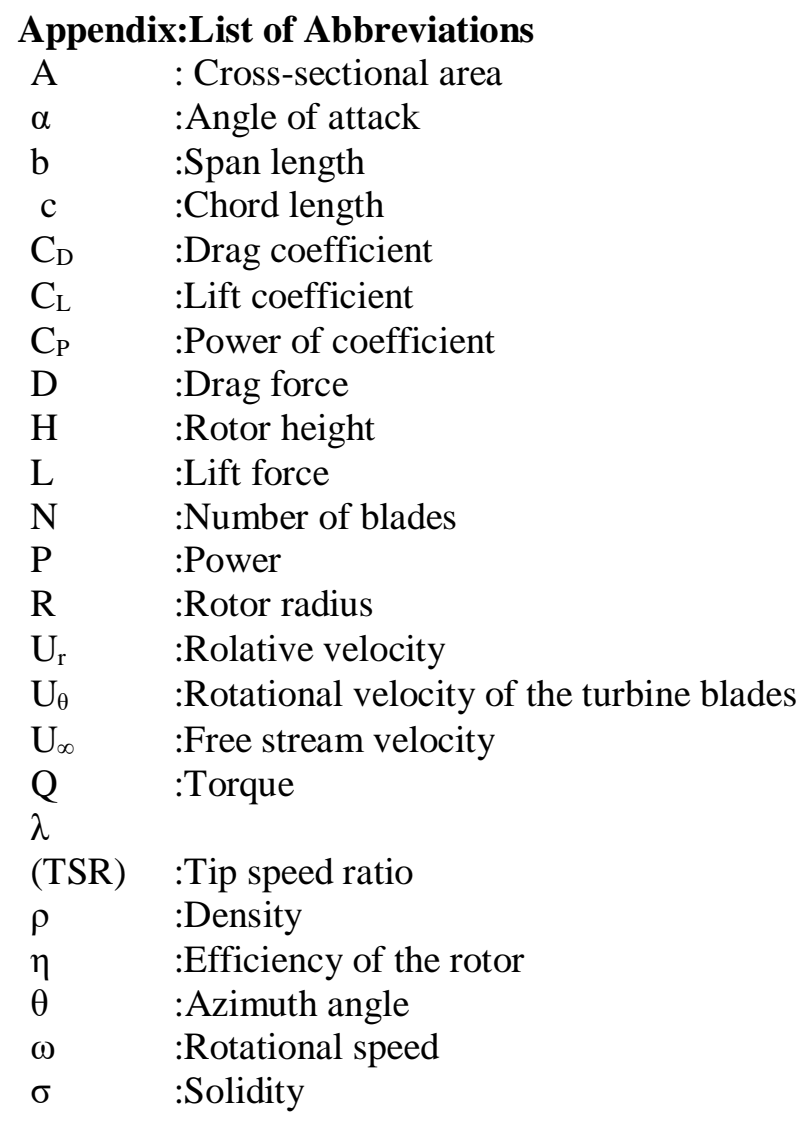

